\title{
Hearing Assessment in CSOM Patients Undergoing Medical Management
}

\author{
Dr.M.Sivakumar ${ }^{1}$,Prof.Dr.A.R.Ali Sulthan ${ }^{2}$ Dr.R.V.Kumar ${ }^{3}$,Dr.K.Vineetha ${ }^{4}$ \\ ${ }^{I}$ Assistant Professor, Department Of ENT,Coimbatore Medical College,India \\ ${ }^{2}$ Professor, Department Of ENT,Coimbatore Medical College,India \\ ${ }^{3}$ Assistant Professor, Department Of ENT,Coimbatore Medical College,India \\ ${ }^{4}$ Junior Resident, Department Of ENT,Coimbatore Medical College,India
}

\begin{abstract}
1.1 Objective

Comparative analysis of hearing in patients undergoing medical management in patients having chronic otitis media during active and inactive period

\subsection{Materials And Methods}

25 patients aged 15-50 years with chronic otits media with conductive hearing loss who undergoes medical management.

1.3 Results

Audiological improvement of around 10-15dB is seen in the study group .

Keywords : Active mucosal disease,chronic otitis media, hearing, medical management, pure tone audiometry,
\end{abstract}

\section{Introduction}

Chronic suppurative otitis media (CSOM) is a chronic inflammation of the middle ear and mastoid cavity. Clinical features are recurrent otorrhoea through a tympanic membrane perforation, with conductive hearing loss of varying severity. Patients with chronic suppurative otitis media (CSOM) respond more frequently to topical therapy than to systemic therapy. Successful topical therapy consists of 3 important components: selection of an appropriate antibiotic drop, regular aggressive aural toilet, and control of granulation tissue

\subsection{Source Of Data}

\section{Materials And Method}

25 patients aged 15-50 years with chronic otits media with conductive hearing loss who undergoes medical management in Coimbatore medical College and Government hospital will be included in the study, after obtaining the ethical committee clearance

1.2 Study Period:

January 2016 - January 2017

1.3 Study Design:

Retrospective study.

\subsection{Study Subjects:}

Patients

- 15-50 years

- chronic otitis media safe type

- patients with intact ossicular chain

- no sensory neural component

\subsection{Sample Size : 25 Patients}

\subsection{Inclusion Criteria}

Patients of age 15-50 yrs with chronic otitis media with active disease who underwent medical management for a period of 1-2 months at Government Medical College Hospital , Coimbatore

\subsection{Exclusion Criteria}

- 1. Pregnant and lactating woman 
- 2. Children $<15$ years

- Sensory neural hearing loss

\subsection{Defining Criteria:}

Chronic inflammation of mucoperiosteal lining of middle ear cleft including mucosa ,tympanic membrane and ossicles characterized by persistent or intermittent ear discharge through tympanic membrane perforation..Ossicular erosion involves erosion of middle ear ossicles resulting in ossicular discontinuity.

\section{Methodology}

The study will be undertaken on patients having chronic otitis media active disease who underwent medical management for a period of 1-3 months at Coimbatore medical college hospital during the study period of one year (January 2016 to January 2017). A total of 25 patients who undergoes medical management for chronic otitis media at Coimbatore medical college hospital were studied. The study is proposed to be conducted after obtaining informed signed consent from the guardians of the patients. The duration of the study is one year from January 2016 to January 2017. The principal investigator, after obtaining informed signed consent from the patient or parents/guardians of the patients to participate in the study.Hearing is assessed using Pure Tone Audiometry before medical treatment. Treatment were performed by the same surgeon. Pure tone audiometry done for each and every patient 1-3 months following medical treatment. Air bone gap evaluated.

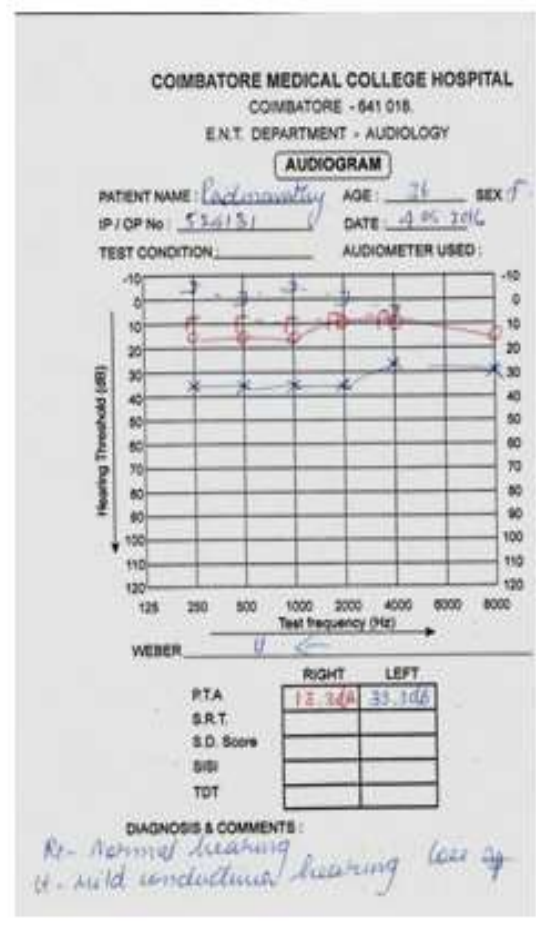

Fig 1.pretreatment PTA

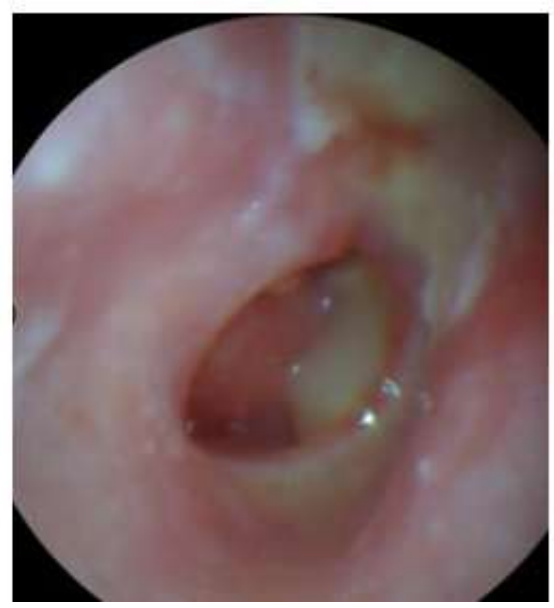

Fig 3.pre \&post treatment TM images

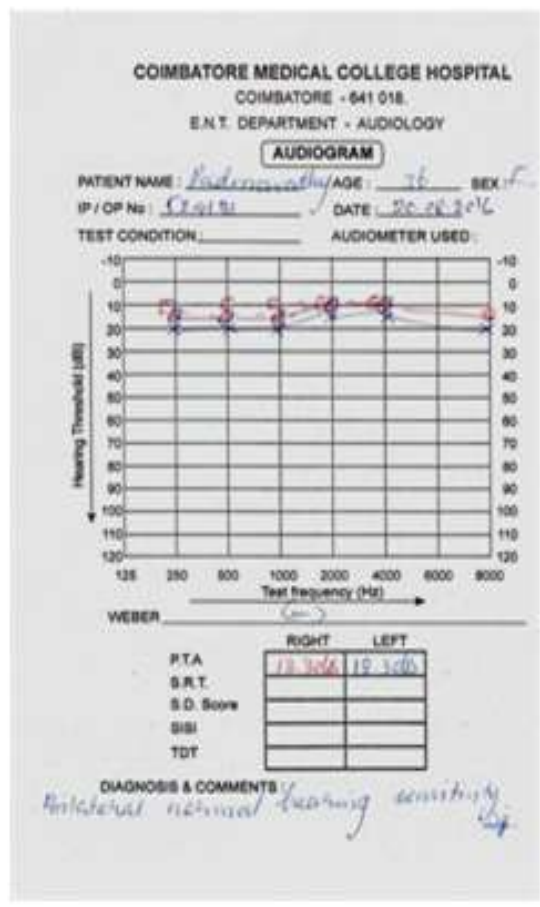

Fig 2. Posttreatment PTA

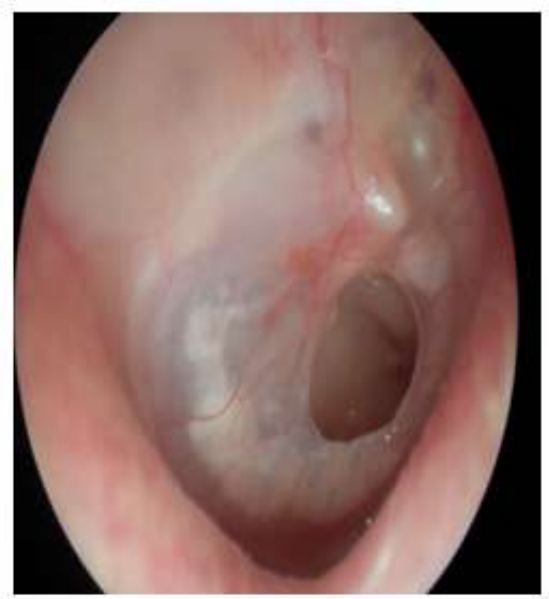




\section{Discussion}

Patients with CSOM that is unresponsive to topical and/or systemic medical therapy with appropriate aural toilet and control of granulation tissue require surgery. Tympanoplasty is performed to eradicate disease from the middle ear and to reconstruct the hearing mechanism, with or without grafting of the tympanic membrane. The initial stage in medical management is thorough aural toilet. It can be done either by dry or wet mopping.

This is most effectively carried out with a microscope and suction which also allows accurate assessment of the extent of ear pathology. However, some clinicians use gentle syringing with saline or antiseptic agent. Gentamicin or neomycin, usually with hydrocortisone, have been the most popular topical agents for many years. More recent studies have compared topical quinolone antibiotics (ciprofloxacin or ofloxacin)with these more traditional agents.

Most common organisms involved in csom safe type are pneumococcus, Hemophilus influenza , moraxella catarrhalis, staph aureus and streptococcal species.As penicillin group is more effective against these agents we used aminopenicillin amoxicillin $40 \mathrm{mg} / \mathrm{kg} /$ day in 3 divided doses and macrolide like erythromycin $30-50 \mathrm{mg} / \mathrm{kg} /$ day available in our institution.

\section{Conclusion}

Hearing improvement of about $10-15 \mathrm{~dB}$ is seen in $70 \%$ of study group patients and less than $10 \mathrm{~dB}$ in $30 \%$ of study group patients having chronic otitis media with active disease who underwent medical management with antibiotics for a period of 1-3 months .

\section{References}

1) Scott brown's otorhinolayngology,Head and neck surgery, volume 3, chapter $237 \mathrm{c}$

2) Glasscock shambaugh surgery of the ear, chapter 27 ,pathology and clinical course of inflammatory diseases of middle ear

3) Erkan M,Aslan T,Sevik E et al.Bacteriology of csom

.Ann Otol Rhinol Laryngol 1994

\begin{tabular}{|l|l|l|l|l|}
\hline S1 No & Name & Age/Sex & $\begin{array}{l}\text { Before Medical } \\
\text { Management }\end{array}$ & $\begin{array}{l}\text { After Medical } \\
\text { Management }\end{array}$ \\
\hline 1 & Lakshmi & $39 / \mathrm{F}$ & $30.3 \mathrm{db}$ & $18.3 \mathrm{db}$ \\
\hline 2 & Chithra & $18 / \mathrm{F}$ & $26.5 \mathrm{db}$ & $18.3 \mathrm{db}$ \\
\hline 3 & Rasathi & $40 / \mathrm{F}$ & $38 \mathrm{db}$ & $35.6 \mathrm{db}$ \\
\hline 4 & Padmavathy & $36 / \mathrm{F}$ & $32.3 \mathrm{db}$ & $18.3 \mathrm{db}$ \\
\hline 5 & Vivek & $23 / \mathrm{M}$ & $38.3 \mathrm{db}$ & $26 \mathrm{db}$ \\
\hline 6 & Saleem & $18 / \mathrm{M}$ & $31 \mathrm{db}$ & $25 \mathrm{db}$ \\
\hline 7 & Sunil & $29 / \mathrm{M}$ & $41.6 \mathrm{db}$ & $23.3 \mathrm{db}$ \\
\hline 8 & Thiruvammal & $47 / \mathrm{F}$ & $35.3 \mathrm{db}$ & $20 \mathrm{db}$ \\
\hline 9 & Shamseena & $25 / \mathrm{F}$ & $36.6 \mathrm{db}$ & $25 \mathrm{db}$ \\
\hline 10 & Suresh & $24 / \mathrm{M}$ & $36.6 \mathrm{db}$ & $31.6 \mathrm{db}$ \\
\hline 11 & Mariyammal & $46 / \mathrm{F}$ & $35.3 \mathrm{db}$ & $40.5 \mathrm{db}$ \\
\hline 12 & Remya & $26 / \mathrm{F}$ & $28 \mathrm{db}$ & $18.3 \mathrm{db}$ \\
\hline 13 & Nallachi & $36 / \mathrm{F}$ & $30 \mathrm{db}$ & $32.6 \mathrm{db}$ \\
\hline 14 & Praveen & $15 / \mathrm{M}$ & $29.6 \mathrm{db}$ & $18.3 \mathrm{db}$ \\
\hline 15 & Praveena & $17 / \mathrm{F}$ & $31.4 \mathrm{db}$ & $20.6 \mathrm{db}$ \\
\hline 16 & Lakshmi & $34 / \mathrm{F}$ & $39 \mathrm{db}$ & $25,6 \mathrm{db}$ \\
\hline 17 & Guruvammal & $45 / \mathrm{F}$ & $34 \mathrm{db}$ & $22 \mathrm{db}$ \\
\hline 18 & Tamilselvan & $45 / \mathrm{M}$ & $38.3 \mathrm{db}$ & $25 \mathrm{db}$ \\
\hline 19 & Poovarasan & $16 / \mathrm{M}$ & $30.3 \mathrm{db}$ & $25 \mathrm{db}$ \\
\hline 20 & Deepa & $29 / \mathrm{F}$ & $38.3 \mathrm{db}$ & $24 \mathrm{db}$ \\
\hline 22 & Gomathi & $36 / \mathrm{F}$ & $31 \mathrm{db}$ & $20 \mathrm{db}$ \\
\hline 23 & Tamilselvi & $20 / \mathrm{F}$ & $32.3 \mathrm{db}$ & $19.6 \mathrm{db}$ \\
\hline 24 & Kaliyammal & $47 / \mathrm{F}$ & $31 \mathrm{db}$ & $28 \mathrm{db}$ \\
\hline 25 & Devraj & $42 / \mathrm{M}$ & $30 \mathrm{db}$ & $18.6 \mathrm{db}$ \\
\hline & & & & \\
\hline
\end{tabular}

